\title{
The investigation of snow-depth with airborne laser scanner In the Shirakami-sanchi world heritage site
}

\author{
石岡 義則*・望月貫一郎*・三谷＼cjkstart歩* \\ 洲濱 智幸*・齋藤 宗勝**・八木 浩司*** \\ 檜垣 大助 $* * * \cdot$ 佐藤 浩 $* * * * *$ \\ Yoshinori ISHIOKA, Kanichiro MOCHIZUKI, \\ Ayumu MITANI, Tomoyuki SUHAMA, Munekatsu SAITOH, \\ Hiroshi YAGI, Daisuke HIGAKI and Hiroshi P. SATO
}

\begin{abstract}
In the Shirakami-sanchi and Yakushima world heritage site, it is important to develop suitable preservation monitoring method with a viewpoint of biodiversity. For this purpose various investigations have been conducted to clarify the forest ecosystem by collecting basic field ecosystem data. But it is not fully carried out to grasp actual forest ecosystem exactlly because of inaccessibility to the monitoring site and its geo-climatological condition. In the meeting of world heritage committee of UNESCO, it is necessary to report site situation and importance of investigation. Hence it has been decided to promote the investigation and research of the both forest ecosystem for the management plan. It is important to develop a monitoring method, using rapid and economical observation method dynamically which we can achieve.

A topographic analysis study has been undertaken to understand the environmental change around Shirakamisanchi, a world heritage site, and make contribution for the maintenance of its biodiversity. It has been understood that snow depth and topographic features may have influence on the vegetation distribution. To map these two factors, airborne sensor was flown twice, autumn and winter, to acquire necessary data, in the south slope of Shirakami-sanchi Kushiishiyama monitoring site. The topographic feature, Digital Terrain Model (DTM), was mapped using autumn data. The snow-depth was calculated by subtracting autumn DTM from winter DTM. The snow depth estimated value, which was $250 \mathrm{~mm}$, was verified by using observed value at Kushiishiyama meteorological observation facilities.
\end{abstract}

\section{1.はじめに}

本研究の対象地域である白神山地は，平成 5 年に我 が国で最初の世界自然遺産として登録された。この国 際的にも顕著で普遍的な価値を有する白神山地の自然

* 株式会社パスコ

** 盛岡大学短期大学部

*** 山形大学

**** 弘前大学

*****国土地理院地殼活動研究センター

「写真測量とリモートセンシング」VOL. 46，NO. 3， 2007
環境を将来にわたって保全していくためには，自然生 態系，特にブナ林の森林構造やその動態を把握し，モ ニタリングで得られた結果を保全管理に反映させてい くことが重要であるとされている。しかし，当該区域 は，深い谷が密に入り組み，30度以上の急傾斜地が半 分以上の地域を占めることに加え，我が国でも有数の 多雪地带であることから，従来方法による広域的な地 上調査が困難な地域として知られ，自然環境の動態に ついても未解明な部分が多々残されていた。白神山地 世界遺産地域核心地域内の斜面での10-100年程度の時 間スケールでの地形変化は，水流による浸食よりも地 滑り等のマスムーブメントによるものが大きいと予想 
されておりこのことを検証するためには，大規模な 地滑りの発生や, 斜面崩壊などの微地形変化が発生し やすい場所を特定するため遷急線が緻密に再現された 地形図が要求される。ところが, 森林・林床に対古る 刈払いが規制されている本地域での従来型の現地測量 は, 極めて非効率で広範にわたる地形図作成は困難で あり, また, 航空測量による地形闵の作成方法も, 従 来型の航空測量では林床の正確な起伏までを表現でき ないのが現状である。

このため, 環境省東北環境事務所環境省 (平成15～17 年度) では, 航空機レーザー計測を活用した森林計測 技術の構築を図り，より精度の高い，広域的に適用可 能な技術として確立し，この技術を基礎として生物生 息地の連続性確保等による生態系ネットワークを構築 していくこととなった。

\section{2. 調査地域}

調查区域は, 白神山地世界遺産地域の核心地域とし, 北限を櫛石山, 南限を摩須賀岳とする南北 $3 \mathrm{~km}$ お よ び赤石川を主軸とする東西 $2 \mathrm{~km} の 6 \mathrm{~km}^{2}$ を対象範囲 として実施した。図 1 は, 2006年 3 月 10 日観測の積雪 面を表し, 赤石川流域を形成する谷は深く $\mathrm{V}$ 字形をな すが, 流域界の尾根付近は比較的緩やかな傾斜を呈し ており，白神山地の特徵でもある我が国有数の典型的 な隆起地形であることがうかがえる。また, 周辺は白 神山地世界遺産地域を代表する白神岳, 真瀬岳, 二ッ 森, 小岳, 青鹿岳などの $1,000 \mathrm{~m}$ 級の山久が鎮座し, 多 雪地带と相まってブナ林を中心とした多様な自然生態 系が育まれていると同時に多くの崩壊地が見られるこ

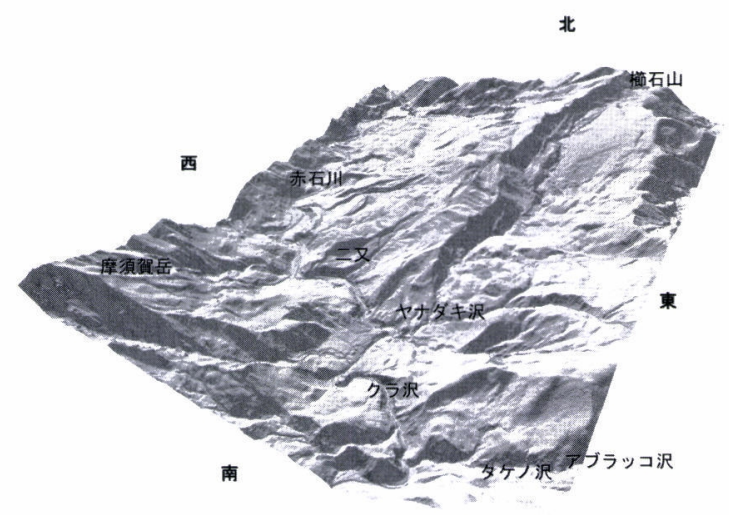

図 1 冬季航空機レーザー計測により観測された積雪面

\section{とも本区域の大きな特徵である。}

航空機レーザー計測の精度検証にあたっては，環境 省東北環境事務所（平成10 14年度）の調查研究デー タが蓄積されている 3 箇所のモニタリングサイト（図 2)において現地測量を行った。サイト1は, 尾根状 地形に位置する高木のブナ林の倒壊によりギャップが 多く確認される。サイト 2 は, 斜面崩壊（地す心゙り） により形成された台地状地形で, 樹冠高 $25 \mathrm{~m}$ を越える ブナ林が均等に生育し, 比較的若齢林带が形成される。 サイト 3 は, 東部入の地滑り後に形成された高木のブ 十林が分布し, 中央から北西にかけては沢状地形の影 響により，中低木が分布する。

\section{3. 検証データ}

\section{1 地 盤 高}

各モニタリングサイトの既設メッシュ杭に対して, トータルステーションにより XY 座標及び地盤高を 付与した。各サイトは, $100 \mathrm{~m} \times 100 \mathrm{~m}$ 程度の面積を有 し, 現地測量によってXYZが計測されたメッシュ杭 が $10 \mathrm{~m}$ 程度の間隔 (図 2 ) で設置される為, 合計 363 地 点（121地点× 3 サイト）を検証データとした。

\section{2 樹 冠 高}

樹冠高の検証デー夕作成にあたっては, 多様な種が 混在するサイト 1 を対象とした。調查にあたっては, 杭を中心とする $10 \mathrm{~m} \times 10 \mathrm{~m}$ 内で，樹冠部が他の樹木で 覆われていない樹木を調查対象として選定を行なっ た。このとき, 樹冠高調查位置はトータルステーショ ンで, 樹冠高を登攀の上, 樹高棒（上方）とエスロン テープ (下方) で計測を行った。

\section{3 積 雪 深}

対象地域は, 1 .に記したように, 急峻な地形等の影 響により，スノーサンプラーによる広域的な積雪深調 査が困難である。そこで, サイト 1 南部に設置された 櫛石山気象観測施設において, 毎時間観測される積雪 深を利用するものとした。積雪面を観測した 2006 年 3 月 10 日は, 日平均 $3,672 \mathrm{~mm}(3,630 \sim 3,711 \mathrm{~mm})$ の積 雪深が観測された。櫛石山気象観測施設の位置は, GPS 測量と周辺地形の状況から判断しプロットを 行った。 

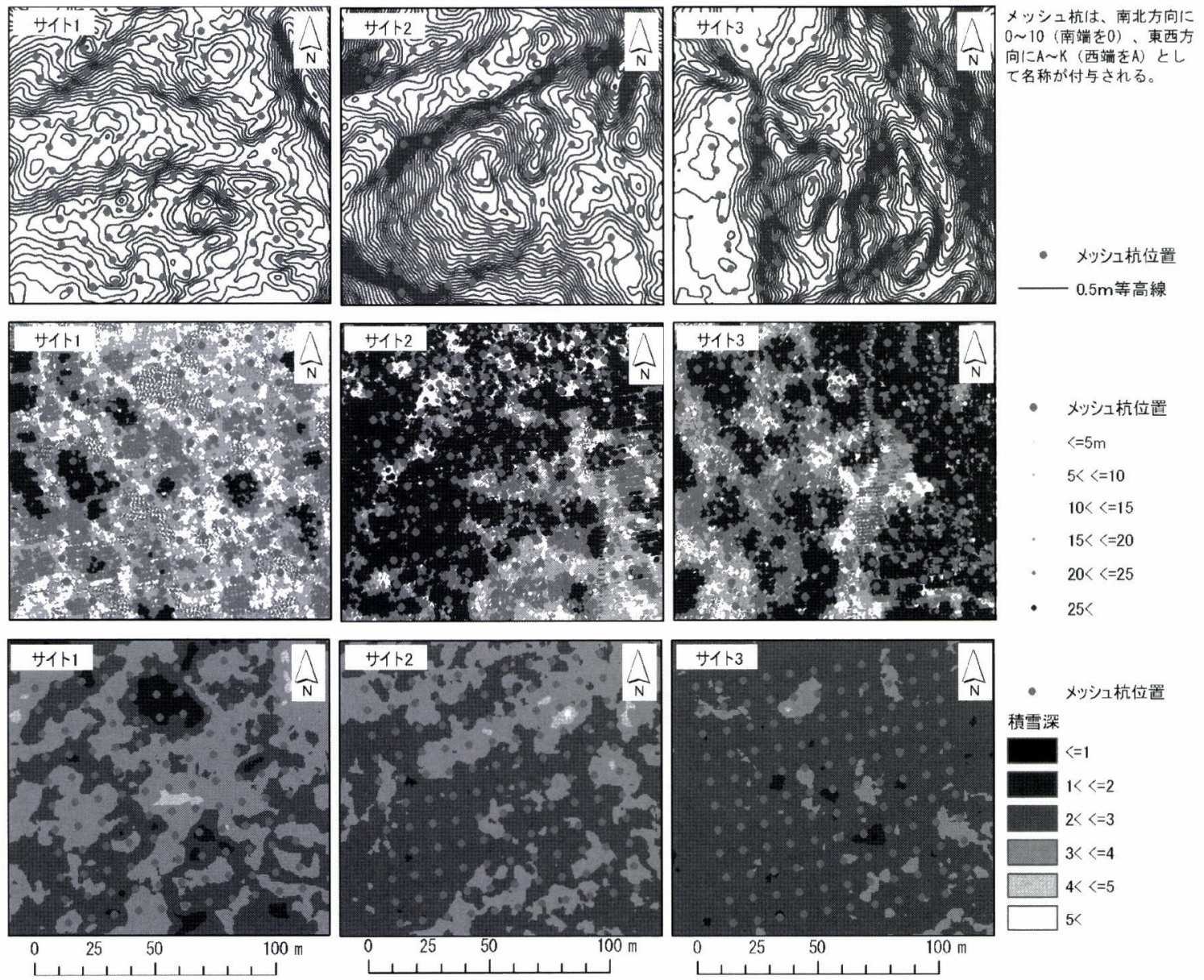

図 2 検証サイトの地形・樹冠高・積雪深分布図

\section{4. 航空機レーザー計測}

航空機レーザー計測にあたっては，LH システムズ 社製 ALS50（Airborne Laser Scanner）を利用し，ス キャンレート $37,700 \mathrm{~Hz}$, 計測パルス数 3 パルス, 計測 間隔 $0.5 \mathrm{~m}$, 基準面標高 $650 \mathrm{~m}$, 対地高度 $1,178 \mathrm{~m}$ の条件 のもとに撮影を実施した。

本研究においては，冬季航空機レーザー計測（2006 年 3 月 10 日撮影）により積雪面を計測し, 落葉期航空 機レーザー計測（2003年10月21日撮影）により推定さ れた地盤高を差し引くことにより, 積雪深を算出し, 地形的特徵と積雪深の分布及び森林構造を概查するも のとした。

\section{5. 精度検証結果}

\section{1 地 盤 高}

地盤高計測結果は, 検証デー夕に対し, $\pm 1 \mathrm{~m}$ 以内 の精度(サイト 1 RMSE $0.86 \mathrm{~m}$, サイト 2 RMSE $0.45 \mathrm{~m}$, サイト 3 RMSE $0.69 \mathrm{~m})$ を示し, 3 箇所の モニタリングサイトのうち, サイト 1 の検証結果に比 較的誤差が多く確認された（図 3 )。

サイト 1 の誤差の大きい区域では, 一様に現地測量 結果より航空機レーザー計測データが高い結果となっ た。これら観測地点は, ギャップに群生するチシマザ サの植生区域であった。現地調查により計測したチシ マザサの高さは2.0〜2.5m であることを考慮すると， 計測誤差の要因は航空機レーザーのラストパルスが, ササの中層葉茎部で反射されたことによる影響と推定 

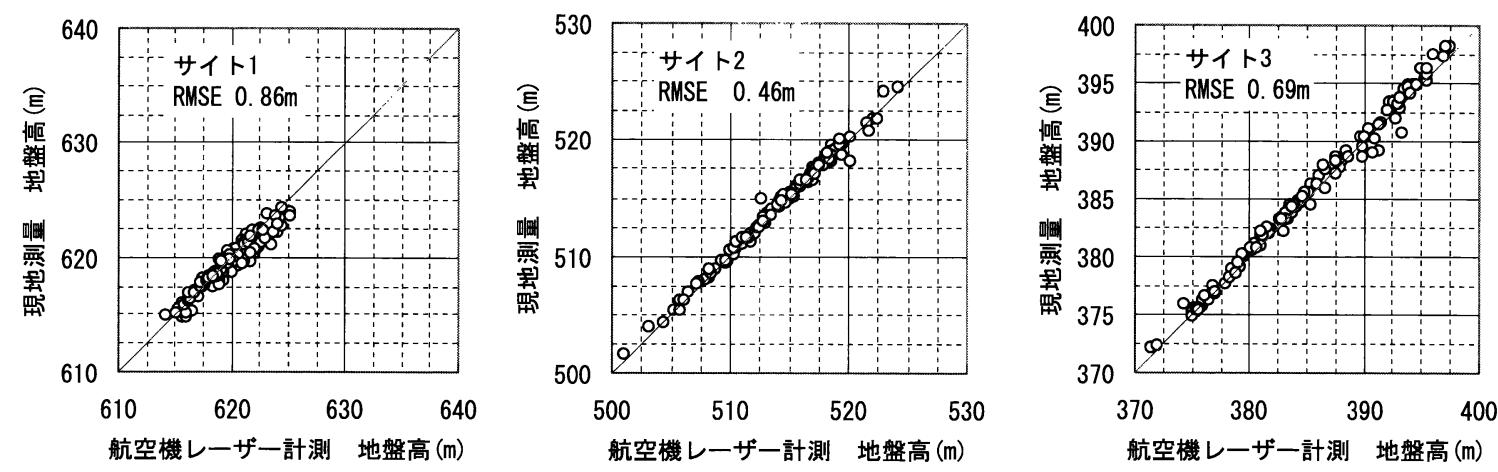

図 3 地盤高精度検証結果

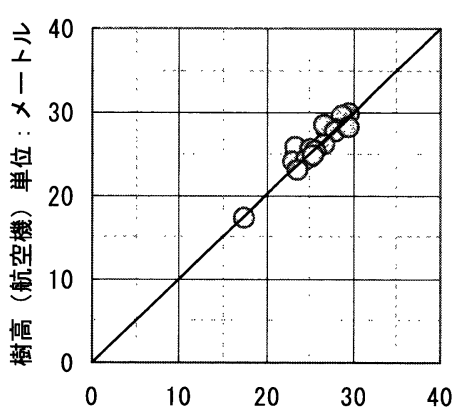

樹高 (現地計測) 単位 : メートル

図 4 樹冠高（プナ）精度検証結果

される。このように, チシマザサが密集する地域で地 盤高が高く計測される可能性が残る。

\section{2 樹 冠 高}

DSM とDTM (地盤高) の差分によって算出される 樹冠高は, ブナの樹冠高計測結果 (計測本数 $\mathrm{n}=19$ )に 対して $1 \mathrm{~m}$ 程度の精度であった(図 4 )。誤差要因と しては，周囲の高木によるレーザー光の遮断が挙げら れた。本研究では，落葉後に計測されたDSMを利用 し，前述したような精度を得ることができた。これは， ブナの枝が密生し，落葉後も樹冠部でレーザー光の反 射が確認されたためである。ホオノキのような枝張り の少ない樹木の場合には，落葉期のDSM による樹冠 高の推定は困難である。

\section{3 積 雪 深}

積雪については，櫛石山気象観測施設における 2006 年 3 月 10 日平均積雪媣 $3,672 \mathrm{~mm}$ に対して推定積雪深 3,420mm を示した。GPS 計測の誤差を考慮し, 近隣10 $\mathrm{m}$ 程度に位置するメッシュ杭の推定積雪深について
も比較材料とした。近隣 3 地点の推定積雪深は, 3,240 $\mathrm{mm}$ (地点 D0, 地点名称は図 2 参照) $3,420 \mathrm{~mm}$ (地点 $\mathrm{E} 0), 3,110 \mathrm{~mm}$ (地点 $\mathrm{F} 0$ ), という結果を示し, 日平均 積雪深3,672mm に対してー252〜ー562mm の較差を 示した。

積雪深推定にあたっては,地盤高推定の較差も含む。 櫛石山気象観測施設周辺では，チシマザサの密集は確 認されないが，密集する地域では実際の積雪より低く 推定される可能性が残る。秋山・佐藤（平成18年）は， 新潟県中越地方芋川流域において，裸地かつ平坦な33 箇所においてスノーサンプラーを用いた積雪樑を実測 し，これを正としてレーザー積雪深（本研究と同様の 手法で推定した積雪深）と対比した結果，その較差は $786 \mathrm{~mm}$ －353mm，較差の標準偏差は $228 \mathrm{~mm}$ であっ たことを報告していることから，本研究で報告した範 囲での較差はあったものと推定される。

\section{6. 積雪と地形因子, 森林構造の検討}

豪雪地带であり比較的急峻な地形が展開する白神山 地（困 5 ）では，雪崩による立地阻害など，積雪がブ ナ林に与える影響が大きい。そこで，地形因子として， DTM (地盤高) から谷地形と尾根地形を抽出し, 樹冠 高や積雪深と比較検討を行った（図 6 )。地形区分の作 成にあたっては，はじめに DTM から地点ごとの流下 方向を算出する。流下方向算出にあたっては， $1.5 \mathrm{~m} \times$ $1.5 \mathrm{~m}$ メッシュ内に隣接する 8 方向から最も落差の大 きい方向を算出し，対象地点が範囲内最小值である場 合は，平滑化処理により最も落差の小さい方向を流下 方向として割り当てるものとした。流下方向が決定さ れることにより，集水域内の水の流れが決定される。 


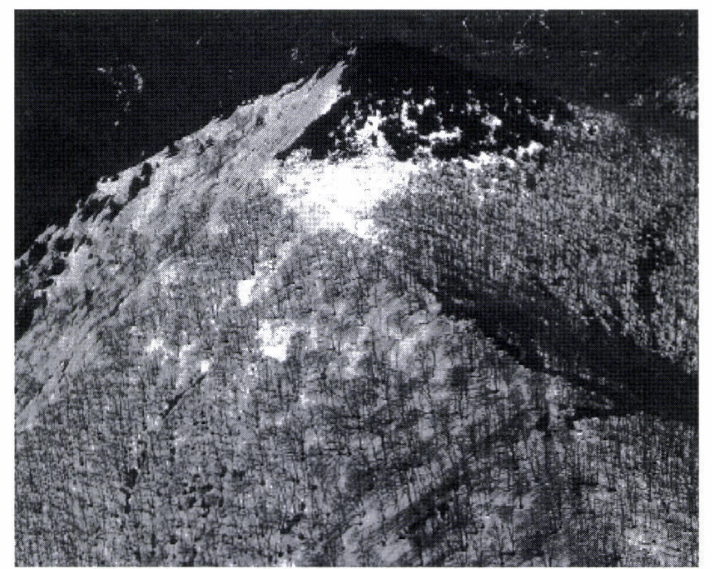

尾根地形の例（樹林帯の疎・密な箇所）

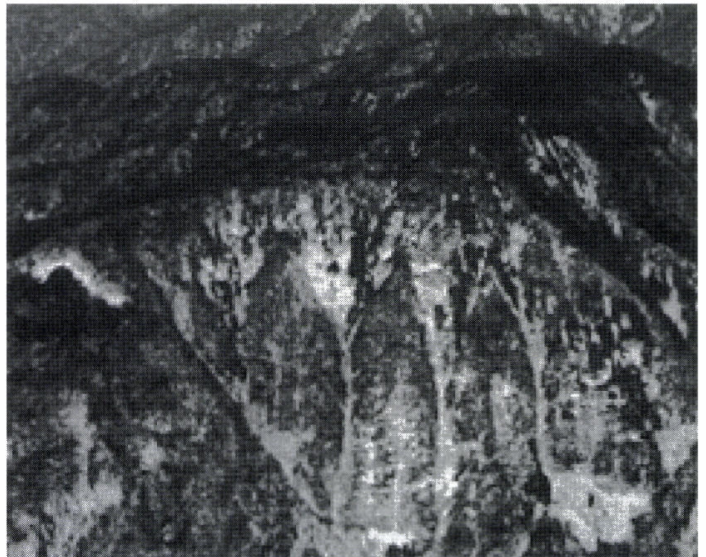

谷地形の例

図 5 白神山地積雪写真（八木浩二, 齋藤宗勝, 牧田 肇 (平成10年))
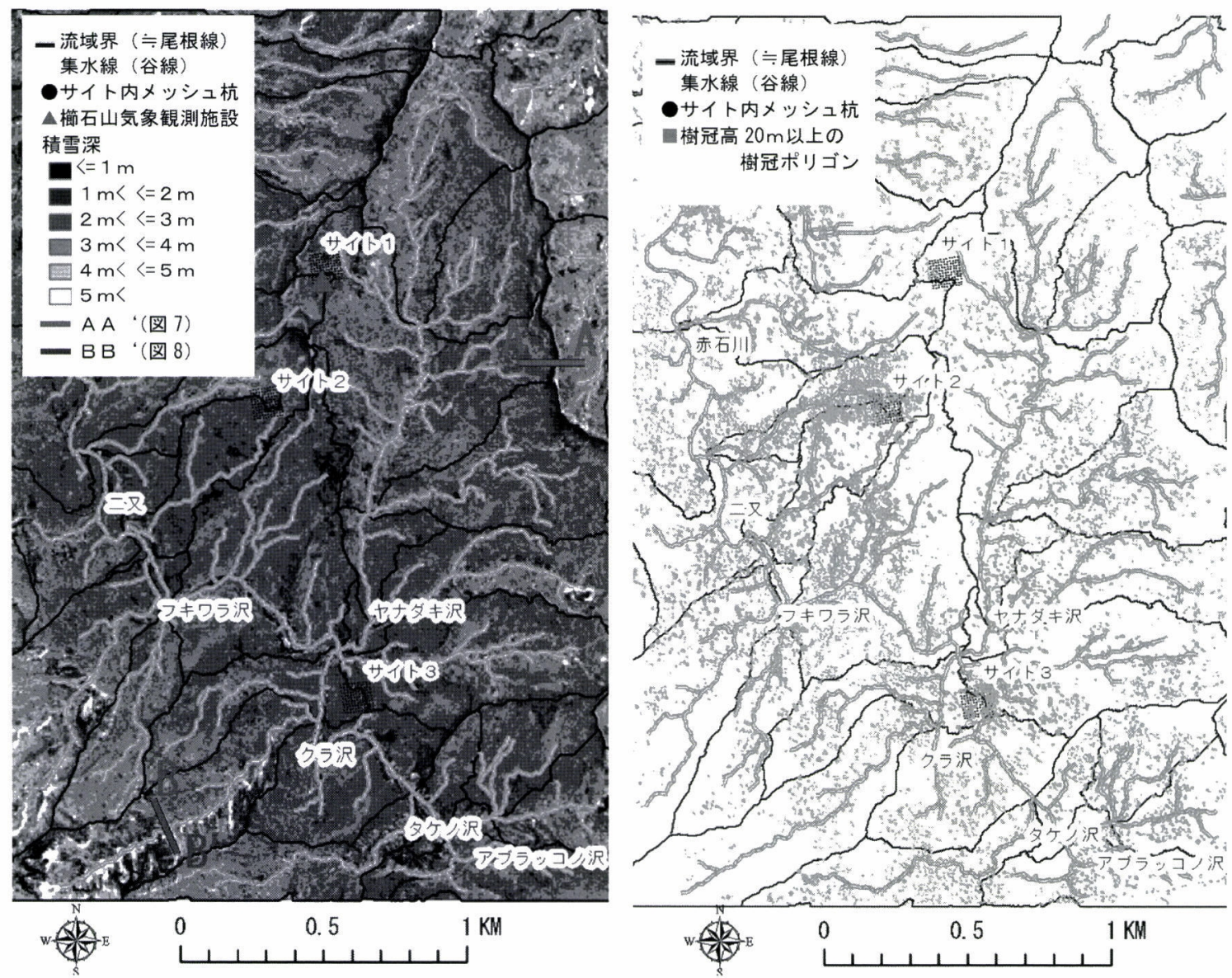

図 6 積雪分布図と高木（樹冠高20m 以上）分布図 


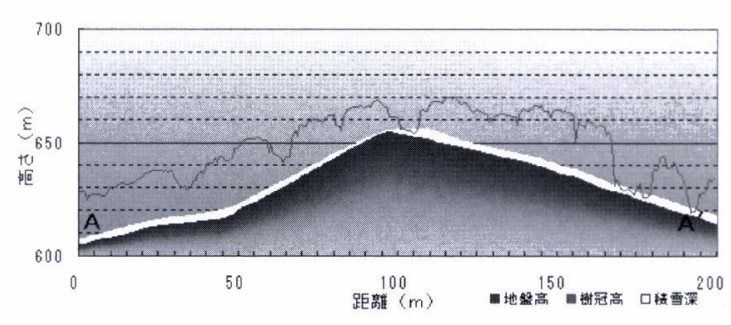

図 7 積雪深分布断面図(1)

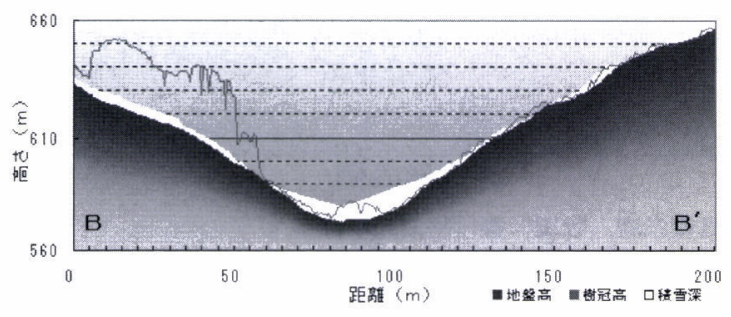

図 8 積雪深分布断面図(2)

ここで, 地点ごとに上流域から集水するピクセル数( 集水面積）を算出し，集水面積が大きい地点が連結さ れる地点では, 谷地形が抽出される。続いて, 流域面 積を定義することによって, 流域界デー夕を作成する。 本研究においては, 対象地域を適当な数に区分するこ とによる尾根線の抽出を目的とするため, 比較的中規 模な流域を対象とした 10 ha を流域面積とするものと した。また，集水線（う谷線）の抽出に利用される条 件は，集水面積が 1 ha 以上の地点とした。

地盤高, 樹冠高, 積雪面の断面困を示す困 7 (困 6 中の断面）は，風雪による東西斜面の樍雪深の差異が 明瞭に認識される。南北方向に尖鋭な尾根を形成する 場合, 冬季においては, 西斜面の雪が風圧の影響で東 斜面に押し出され，斜面方位による積雪深の違いが定 量的に確認できた。また, 困 8 (図6 中の断面) では, 摩須賀岳（図1）に代表される谷地形では，吹きだま りの影響で高木が生育していない。

本研究において確認された森林形態と地形区分・積 雪深の関係を以下にまとめる。

(1) 尖鋭な尾根の周辺部では, $20 \mathrm{~m}$ 以下の中低木が生 育する場合が多い（図 6, 7)。

（2）急峻な斜面に井まれる谷部では，冬季の「雪崩」 や「吹きだまり」の影響で樹木が高木となりにくい
(困 6,8 )。

\section{7.おわりに}

白神山地に形成されるブナ林は，比較的急峻な地形 上に展開し, 台風，風雪，更には斜面崩壊等の様々な 要因により, 倒木や幹折等が絶えず繰り返されている。 そのため, ブナ林の動態を調査するためには，多面的 観点からのモニタリング，並びに情報管理が必要とさ れる。環境省 東北地方事務所（平成10～14年度）に おいては，環境情報を的確に収集することに加えて， 動植物への影響を最小限に抑之るため，モニタリング 項目ごとに適正な調查時期や回数が規定され，地盤高 推定に代表される広域モニタリング手法の開発が急務 であると指摘された経緯がある。本研究では, 航空機 レーザー計測によって地形, 樹冠高, 積雪深を作成し, 森林動態の解明に活用できることが示された。今後は, 各主題罒の推定精度を高めるとともに，適切な撮影頻 度と撮影時期の検討から効率的なモニタリング技術を 確立することが必要である。

\section{謝辞}

本研究は, 環境省東北地方事務所 (平成15～17年度) により実施した。ここに記して謝意を表す。

(受付日2007.3.7, 受理日2007.5.11)

\section{参考文献}

環境省 東北地方事務所(平成15～17年度), 白神山地 におけるブナ林の森林構造及び動態の解明に関する 調查研究業務報告書.

環境省 東北地方環境事務所 (平成10１4年度), 白神 山地世界遺産地域の森林生態系保全のためのモ二夕 リング手法の確立と外縁部の森林利用との調和を図 るための森林管理法に関する研究報告書.

八木 浩二, 齋藤 宗勝, 牧田 肇(平成 10 年), 白神 の意味, 自湧社.

秋山 實・佐藤 浩(平成18年), 航空レーザー測量に よる積雪深分布の計測と積雪相当水量の推定, 写真 測量とリモートセンシング，45(2)，24-33. 